\title{
Mastermind-Like Protein 1
}

National Cancer Institute

\section{Source}

National Cancer Institute. Mastermind-Like Protein 1. NCI Thesaurus. Code C114487.

Mastermind-like protein 1 (1016 aa, $108 \mathrm{kDa}$ ) is encoded by the human MAML1 gene.

This protein is involved in the regulation of notch-dependent gene transcription. 